\title{
Cooperation and Competition among Clustered MSEs in East Java
}

\author{
ArifHoetoro \\ Faculty of Economics and Business, Universitas Brawijaya, Indonesia
}

\begin{abstract}
There has been a common picture in economic development that micro and small enterprises (MSEs) tend to conglomerate in various clusters for the sake of gaining location advantages. These MSEs then create inter-firm linkages and business strategies as the two play an important role in their performance. By taking selected manufacturing MSEs that operate in various small industrial clusters in East Java, Indonesia, this research examined the relationships between the inter-firm linkages and business strategies applied simultaneously by MSEs and their impacts on the firm's performance. Viewed from the perspective of a co-opetition strategy, the results of this study revealed that some types of inter-firm linkages and business strategies matter for the MSEs' performance. However, within small industrial clusters, inter-firm linkages seem to be less effective compared to business strategies in affecting a firm's performance.
\end{abstract}

\begin{abstract}
Abstrak: Terdapat sebuah gambaran umum dalam pembangunan ekonomi bahwa usaha mikro dan kecil (UMK) cenderung beraglomerasi di berbagai klaster agar dapat memeroleh manfaat lokasi dari aglomerasi usaha tersebut. Untuk alasan ini UMK kemudian menjadikan kaitan usaha antar perusahaan dan strategi bisnis sebagai instrumen yang penting dalam meningkatkan kinerja usaha. Dengan memilih UMK pengolahan yang beroperasi di berbagai klaster industri kecil di Jawa Timur, Indonesia, penelitian ini menguji hubungan antara kaitan usaha antar perusahaan dan strategi bisnis yang diterapkan secara simultan oleh UMK dan dampaknya terhadap kinerja perusahaan. Ditinjau dari sudut pandang strategi coopetition, penelitian ini mengungkapkan bahwa beberapa tipe dari kaitan usaha antar perusahaan dan strategi bisnis sangatlah penting bagi kinerja UMK. Namun demikian, dalam klaster industri kecil kaitan usaha antar perusahaan tampak kurang efektif dalam memengaruhi kinerja perusahaan jika dibandingkan dengan pengaruh strategi bisnis.
\end{abstract}

Keywords: business strategies; co-opetition strategy; East Java; inter-firm linkages; micro and small enterprises (MSEs') performances; small industrial clusters

JEL classification: L19

* Corresponding author's e-mail:hoetoro@ub.ac.id 


\section{Introduction}

It has been a common feature that micro and small enterprises (MSEs) tend to conglomerate in certain clusters to achieve location advantages. Within these clusters, the MSEs develop various kinds of cooperation among themselves by creating inter-firm linkages either forwardly, backwardly, or horizontally. At the same time the MSEs have to harmonize such cooperation with their competitive behavior as a strategy to obtain the benefits of joint actions and competitive advantages from the clusters.

This study examined the factors that influence firms performances in small industrial clusters in East Java by analyzing the existence of their inter-firm linkages and business strategies and their impacts on the performance of the MSEs operating in such clusters. The question that we looked to address was whether these inter-firm linkages and business strategies performed an appropriate role in achieving both common interests and private gains. Also, a possibility exists to inquire into the strength of the inter-firm linkages and/or business strategies that affect the performance of the individual MSEs.

In many countries, clusters are increasingly becoming the design for industrial and innovation policies that focus on territorial factors, as they are able to encourage entrepreneurship, learning and productivity improvements (UNIDO 2010). It is reasonable therefore, that many scholars in the field of strategic management and economic development observe how clusters influence firm's performance (Kongmanila and Takahashi 2009). It is because the cluster approach focuses on linkages among the actors (firms and other related agents) in the value chain in producing products and services. The ap- proach exceeds the boundaries of simple horizontal networks in which firms operate in the same end-product market and industrial group, only employing a collective marketing or purchasing policy.

The relevance of clustering as an optional strategy for the MSEs' development in many developing countries has dominated a lot of discussions in the economic development literature. However, there has been a lively debate on how to explain the dynamics of the MSEs' efforts in improving their performance within the clusters. The existing literature tends to mainly focus on interfirm cooperation (Schmitz 1995; Sandee et al. 1994; Nadvi 1999; Sato 2000; Kongmanila and Takahashi 2009) so that they neglect other essential features that should be included in analyzing the nature of small industrial clusters, such as the business strategies applied by the clustered MSEs. On the other hand, studies that place more emphasis on the competitive aspects of clusters (Porter 1990; 2000) seem to lack substance by not featuring much about how such clustered MSEs build inter-firm cooperation in their clusters.

By using evidence taken from various small industrial clusters in East Java, this study argues that both inter-firm linkages and business strategies matter for the MSEs' performance. This study also proposes that in order to assess such triangular relationships simultaneously, an integrated model should be constructed. This, it is envisaged will allow us to explain two possibilities, either this simultaneity has a significant contribution to the MSEs performance, or whether each component strengthens another component for achieving competitiveness. It is expected that the model will be able to provide a more comprehensive picture of the MSEs' develop- 
ment, specifically in this context for the MSEs operating in small industrial clusters in East Java.

This paper proceeds to a literature review that underlies the concept of the simultaneity of inter-firm linkages and business strategies within the MSEs viewed from coopetition strategy perspective. The theoretical reviews then derive hypotheses that would be tested by regression analysis. By using the survey data, indices of the performance of the MSEs, inter-firm linkages and business strategies variables are generated and regression analysis is carried out to assess whether there are significant relationships between the three variables. Finally, discussions and conclusions about the results of the models will be presented.

\section{Literature Review}

In the existing studies on inter-firm linkages, business strategies, and firm performance, the studies conducted by many researchers either in developed or developing countries mostly only paint a partial picture to explain such relationships. This study proposes to pay great attention to the relationships between the three variables which are constructed in an integrated model. It is expected that the model will present a comprehensive picture of the MSEs' development, when operating in small industrial clusters.

\section{MSEs Clusters in Indonesia}

The development of MSEs in Indonesia has commonly featured them forming enormous clusters either in rural or urban sectors. Some clusters were established by local governments but most of the clusters grew naturally. Generally, those clusters contain firms involved in traditional activities which are found in certain communities, with specific areas and products (Tambunan 2006), but they provide insights into essential factors influencing industrial cluster gestation and prosperity (Weijland 1999). Therefore, the MSE clusters become an industrial seedbed and a policy target to improve entrepreneurship in Indonesia (Weijland 1999).

As a policy target for improving the people's economy, the government usually provide various technical and financial programs through the MSE clusters. It is perceived that the clusters can facilitate a localfirm's web or inter-firm linkages for such MSEs to yield a better performance in its business (Ismalina 2009). However, Sandee et al. (1994) pointed out that the results of the government's programs varies among clusters, dynamic clusters will tend to show a positive impact from the programs. Furthermore Tambunan (2006) stated that successful cluster development needs the capacity to access growing markets which is accompanied by policy making based on a diagnosis of the cluster's potential, needs and constraints.

Facing the current globalization trend, there is a need to strengthen the entrepreneurial drive and competitive potential of smallscale firms by developing strategies that increase economies of scale with respect to production, management, and marketing. Kristiansen (2003) stated that all these strategies could be achieved by formatting linkages and collaboration arrangements which are perceived as continuous relationships between the economic actors regulated by contracts and networks to develop social or cultural capital. Ismalina (2009) moreover revealed that the presence of such linkages is very essential for developing the MSE clusters in Indonesia. This is more beneficial when 
the linkage could harmonize market and social relationships as MSEs in clusters need balance in pursuing private gains and common interests for utilization of the cluster's resources. In this regard, assistance programs still need further improvements and their frequency should be intensified (Tarmidi 2005) by focusing on the real needs of the clustered MSEs.

\section{Inter-Firm Linkages}

Experience has shown the importance of inter-firm linkages for creating the industrial texture essential to the growth of an enterprise, and to the economic development of a specific country in general (Vangstrup 1997; Albu 1997; Smallbone 2007). Through these linkages, firms can pave the way to acquire information on products of interest produced by various enterprises at different levels, including prices and regular supplies of inputs, the availability of credit, skilled labor, and markets (Lemma 2001).

In Indonesia, inter-firm linkage has been developed by the MSEs as a specific strategy to improve their capacity and innovation (Sato 2000; Kuncoro and Supomo 2003). Posthuma 2003). This commonly appears in the form of clustering, which is perceived as a feature of the rural industrialization and production specialization of entire villages (Weijland 1994). For example, this rural industrialization can be found in the manufacture of roofing tiles in Boyolali (Sandee et al. 1994) and of teak wood furniture in Jepara (Posthuma 2003; Roda et al. 2007). Another notable example in this regard may be the rural metal-casting enterprises in Ceper, Central Java. According to Sato (2000) those inter-firm linkages have succeeded in promoting the MSEs development in such districts. When the MSEs in such rural industrial clus- ters developed subcontracting ties with assemblers in the modern sector the linkage provided benefits beyond sales of their product. Rather, many firms have been stimulated to improve their innovation and technological capabilities through the linkage system.

Hence, efforts to strengthen mutually beneficial inter-firm linkages among the MSEs have become the heart of the value chain development. This value chain development could be grouped into two major forms; first, vertical linkages, they are backward and forward linkages; and second, horizontal linkages (Miehlbradt and McVay 2006). To obtain positive outcomes from the linkages, Miehlbradt and McVay (2006) pointed out that the outcomes will be present when there is a strong market drive for the linkages, strong investment from many businesses in the chain, and a market system in place to replicate improved practices.

Backward and forward linkages refer to the vertical relationship, that is, a relationship in which the core enterprises produce the products and services that are sold to final consumers, and enterprises that supply inputs such as raw materials, and intermediate goods and services that are used in the assembly of the final product (Mazzola and Bruni 2000). Horizontal linkages on the other hand refers to enterprises that produce the same or similar goods and services at a specific level in the value chain ( $\mathrm{Li}$ and Fung 2006).

During the development process, both backward and forward linkages play an essential role. This is because they can speed up the transformation of economic sectors and generate widespread economic growth when an expansion in one sector through these linkages has emerged (Hirschman 1988; McCartney 2006). As a result, the develop- 
ment of the MSEs will be strengthened when they build these linkages since the linkages allow them to gain better access to inputs and raw materials, create a pool of skilled workers, and open up new overseas markets (IDS 1997).

Meanwhile, within a horizontal linkage, the MSEs can collaborate in activities such as inter-firm arrangements to conduct product development, share the cost of specialized services or equipment, collect marketing information, and supply markets (Henry et al. 1997). In doing so, many options are available to the MSEs, including which markets to target, the extent of up-grading, and the means to enter into contracts with lead firms. The benefits of horizontal linkages also provides the MSEs with the economies of scale and access to information and markets normally available only to larger firms (Ayyagari 2006).

However, an effective inter-firm linkage developed among the clustered MSEs needs a certain kind of social cohesion. The existence of this social cohesion among the clustered MSEs will tailor efforts to improve the various firms' performance. Knorringa and Staveren (2006) in their comparative research on Vietnamese and Ethiopian MSEs indicated that social cohesion or social capital significantly contributed to a firm's performance. While, Ismalina (2009) in her research on ceramic clusters in Yogyakarta, Indonesia, proved that inter-firm linkages sometimes produce some negative aspects of cooperation, which can be eliminated by promoting trust and other social cohesions. The presence of both the social and economic factors is very essential to gain advantages from the inter-firm linkages.

\section{Business Strategies}

The rationale to introduce the business strategies of MSEs operating within an inter-firm linkage mechanism is based on the idea that, due to their resource heterogeneity, the MSEs actually still need to have dynamic capabilities, that is, the ability to connect internal strength with external needs (Janczak and Bares 2010). Parrilli (2001) stated that some factors, such as the linkage of a cluster to an international market and its economic dynamism, power relations amongst firms within the cluster, and the types of firms in it will affect firm heterogeneity within a cluster. As such, the MSEs that operate within inter-firm linkages still develop and implement their own business strategies.

In the MSEs context, since their approach to strategy formation has been described as informal, implicit, intuitive and incremental (Cragg et al. 2002), the conceptualization of a business strategy for the MSEs varies. Cragg et al (2002) stated that studies of the MSEs' strategy have failed to provide a consensus model of strategy for such enterprises. Different studies have produced different typologies and not all types are necessarily present in all industries. This lack of consensus could, in part, be due to the focus on implicit rather than explicit strategy by the MSEs, which makes strategy in those enterprises more difficult to study.

According to $\mathrm{Ha}$ (2002), business strategies focus on improving the competitive position of a company's or business unit's products or services. In a small firm setting, Kotey and Harker (1998) postulated that activities which constitute a strategy can be 
grouped into functional areas and they are at the operational level. These strategic activities are short-term and cover areas such as marketing, finance, human resource, production, and research development (Kotey and Harker 1998; Ha 2002). Besides, two strategy types are proposed namely proactive strategy (associated with high performance levels) and reactive strategy (associated with relatively lower performance levels) and that all firms adopt these strategies in varying degrees. The MSEs may therefore, be classified by the position of their strategies on the proactive-reactive continuum.

\section{Performance}

Given the importance of small businesses to an economy, the performance of these small firms is an issue of continuous concern to policy makers, owner-managers and their advisors (Maes et al. 2003). However, there have been disagreements related to the terminology used, the level of analysis, and the concept of the performance of small and medium enterprises ( $\mathrm{Ha} 2002)$.

Chong (2008) argued that a small firm can measure its performance using financial and non-financial measures. Walker et al. (1999) also proved that a small firm's success can range from the purely financial to the non-financial. In this regard, gross sales (Delmar 1997) and gross profit (O'Regan et al. 2004) can be used as financial performance indicators, and firm productivity ( $\mathrm{Fu}$ et al. 2008) can be used as a non-financial performance indicator. Meanwhile, Freel (2003) used innovation as an indicator in the association with external linkages and found that the influence of various types of innovationrelated networks was non homogenous.

Above all, there is another issue related to the sources of data used to develop the construct of a small firm's performance. Lillo and Lajara (2002) argued that data on the performance of a firm can be obtained either from primary or secondary data. They suggested that the subjective measurement of performance can be used over objective data for several reasons. First, small firms are often very reluctant to provide "hard" financial data. Second, objective financial data are not publicly available, making it impossible to check the accuracy of any reported financial performance figures. Third, assuming that accurate financial data were reported, such data on small firms are difficult to interpret. Finally, absolute scores on financial performance criteria are affected by industrial-related factors. Similarly, Ha (2002) and Garg (2003) highlighted that subjective assessments can be used as a measurement method since obtaining the data of small firms' performances are often difficult due to their deficiencies in accounting records and administrative matters.

\section{'Co-opetition' Strategy}

'Co-opetition' strategy perspective refers to a complex structure of firms interdependence where cooperation and competition are simultaneously interconnected (Dagnino and Padula 2002; Morris et al. 2007; Solitander and Tidström 2010). For the MSEs, due to their limited resources and vulnerability to environmental conditions, having collaborative relationships with competitors represents a viable strategy (Machikita and Ueki 2010). Morris et al (2007) stated that such relationships provide small firms with a means of leveraging resources, a useful method for protecting their market position, and a type of firm asset that can produce collaborative advantages. In the same vein, as Gnyawali et al (2006) pointed out, the firms need to manage the paradox of si- 
multaneous competition and collaboration, manage a fine line between cooperating with partners, and maintain a posture of vigorous competition with rivals including those same partners.

Hence, Makkonen (2008) viewed coopetition as a circumstance rather than a permanent, stable state in the relationship. Within co-opetition, firms share resources, competencies or capabilities, but they also have to struggle for the same limited resources and the best performance. Depending on the context, firms sometimes need each other more and mostly cooperate among themselves. Sometimes the relationship may include more competitive elements, and at times both cooperation and competition occur equally (Makkonen 2008). Bengtsson and Kock (2000) divided these degrees of coopetition in three types, they are; 1) cooperation-dominated, 2) competition-dominated, and 3) equal relationships. Furthermore, Bengtsson and Kock (2000) stressed that two or more enterprises cannot compete exactly within the same activity in which they are cooperating. Therefore, MSEs tend to engage in cooperation in activities that are far from the customer and compete in those near to the customer.

To maximize the degree of co-opetition is a strategic option for (small) firms involved in inter-firm cooperation. Edström and Högberg (2007) stated that there is an interaction between the strategic vision and goals, internal structure, resources, and the firm's environmental interdependencies. Here, motives for inter-firm cooperation such as economic efficiency, risk sharing, control of existing interdependencies and the need for resources utilization will depend on the strategic context. Le Roy and Yami (2009) stressed that as firms must compete and cooperate simultaneously within the same field, they are led to change their mental models. This is both in terms of the choice of the relevant strategy with competitors and in terms of the management of the cooperative structure.

\section{Hypotheses}

In light of the above discussions, it is clear that the inter-firm linkages and business strategies determine the ability of MSEs by offering them several opportunities to upgrade internal resources and capabilities. This research proposed to pay great attention to this aspect, by studying the relationship of interfirm linkages, business strategies and the performance of MSEs which were constructed into an integrated model. The model to some extent differed from existing research, which had merely examined the relationship of the three variables in partial measurements.

In the existing studies on the subjectmatter, the researchers, either in developed or developing countries, mostly paint a partial picture of such relationships. Consequently, the existing research fails to show the dynamic outcomes of how the MSEs utilize the inter-firm linkages and business strategies simultaneously in order to achieve better performance. The failure to construct these variables in an integrated model will lead to the failure in presenting a comprehensive picture of the MSEs' development.

In the case of manufacturing MSEs operating in various small industrial clusters in East Java, it is believed that cooperative behavior and internal strategy are important factors for the development of the small industrial clusters. As a result, the types of inter-firm linkages (i.e. backward, forward, and horizontal linkages), and business strategies (i.e. finance, marketing, HRM, R\&D, and 
operational strategies) applied simultaneously by the MSEs should have a positive impact on the firms' performance. Based on the discussions aforementioned, two hypotheses can be developed as follows:

Hypothesis 1: The significant relationship between the vertical and horizontal linkages to the MSEs'performances varies by market conditions.

Hypothesis 2: The impact of inter-firm linkages to the clustered MSEs' performances is less effective than their business strategies.

\section{Research Sampling and Models}

\section{Research Sampling}

This study collected information on the inter-firm linkages, business strategies, and firms' performance by using a field survey that was carried out at 12 selected clusters dispersed in eight regencies of East Java. The clusters are listed in Table 1.

Based on these 12 clusters, the study deliberately selected types of clusters ranging from small to big, dependant on the number of firms in each cluster. From this selection the survey found 240 respondents dispersed in all the selected clusters.

Meanwhile, the questionnaire used for the survey adopted the work of Ha (2002) and Kongmanila and Takahashi (2009) as its basis. It was conducted from August to October of 2013, which was followed by a focused group discussion (FGD) with respondents from the furniture cluster in the sub district
Table 1. The Sample

\begin{tabular}{lll}
\hline No. & Regency/City & Cluster of MSEs \\
\hline 1. & Sidoarjo & Leather shoes production \\
2. & Mojokerto & Leather shoes production \\
3. & Magetan & Leather processing \\
4. & Pasuruan & - Furniture \\
& & - Automotive components \\
5. & Malang & - Furniture \\
6. & Batu & - Food processing \\
7. & Blitar & -Stone handycraft \\
& & - Food processing \\
8. & Kediri & - Fandycraft \\
\hline
\end{tabular}

of Tunjung Sekar, in Malang. The FGD was conducted on the $1^{\text {st }}$ of November 2013 to explore qualitative explanations of the dynamics of business behavior among such clustered MSEs.

\section{Independent Variables}

The independent variables consist of the inter-firm linkages and business strategy variables. The inter-firm linkage variables include the backward, forward, and horizontal linkages, while the business strategy variables include finance, marketing, HRM, R\&D, and operational strategies. To operationalize these two independent variables, 40 questions were subjectively measured in a five-point Likert scale at "never" (1), "rarely" (2), "sometimes" (3), "often" (4) and "always" (5). All these question items are listed in Table 2 and Table 3. 
Gadjah Mada International Journal of Business -September-December, Vol. 16, No.3, 2014

Table 2. Items for Inter-firm Linkages

\begin{tabular}{|c|c|}
\hline \multirow[t]{5}{*}{ Backward Linkage } & Maintain the linkage with down-line partner \\
\hline & Receive production inputs regularly \\
\hline & Delay of input/material/product delivery \\
\hline & Provide technical support \\
\hline & Provide financial support \\
\hline \multirow[t]{5}{*}{ Forward Linkage } & Maintain the linkage with up-line partner \\
\hline & Receive orders regularly \\
\hline & Receive financial support \\
\hline & Receive technical support \\
\hline & Receive marketing channels \\
\hline \multirow[t]{5}{*}{ Horizontal Linkage } & Share information \\
\hline & Share orders \\
\hline & Joint marketing \\
\hline & Joint buying of inputs \\
\hline & Joint labor training \\
\hline
\end{tabular}

Table 3. Items for Business Strategies

Finance

Marketing
Use outside borrowed funds

Search for cheaper sources of finance

Re-invest the profit earned

Maintain the large cash balance

Provide installment facility to consumers

Explore new method for marketing

Advertise the product

Price the product lower than competitors

Emphasize high sales turn-over

Follow-up on customer complaints 
Continued (Table 3)

Human Resource Development

Research \& Development

Operation
Involve the employees in decision making process

Asses employee's performance

Asses employee's satisfaction

Encourage constructive criticism from employees

Provide training for all employees

Explore new information

Emphasize on product quality

Follow activities in related organization

Attempt to predict customer tastes

Attempt to predict industry trends

Change or revise operating methods

Acquire the knowledge of competitor activity

Emphasize on cost reduction

Evaluate firm target with business plan

Keep high inventories or stocks

\section{Dependent Variable}

The dependent variable of the study included five performance criteria of the firms, which were measured by indicators including total sales, net profits, assets, the number of full-time employees, and worker productivity. All these indicators were quantified by subjective measurement which were designated in a five-point Likert scale ranging from (1) "decrease", (2) "no change", (3) "increase 1 percent - 25 percent", (4) "increase 26 percent - 50 percent", and (5) “increase $>50$ percent". The respondents were asked to state the performance indicators that signify their trend in the last three years. (2011-2013).

\section{Control Variables (CV)}

To further strengthen the findings of the study, it required a regression analysis with some control variables. In this regard, the control variables include the firm's age, size, the entrepreneurs' age (as a proxy for working experience), and the entrepreneurs' education level.

\section{Models}

In order to test the hypotheses stated above, the models utilized an ordinary least squares (OLS) calculation. The equation for these models was as follows:

$$
\begin{aligned}
\mathrm{Y}_{\mathrm{ki}}= & \beta_{0}+\beta_{1 \mathrm{i}} \mathrm{X}_{1 \mathrm{i}}+\beta_{2 \mathrm{i}} \mathrm{X}_{2 \mathrm{i}}+\beta_{3 \mathrm{i}} \mathrm{X}_{3 \mathrm{i}}+\beta_{4 \mathrm{i}} \mathrm{X}_{4 \mathrm{i}}+ \\
& \beta_{5 \mathrm{i}} \mathrm{X}_{5 \mathrm{i}}+\beta_{6 \mathrm{i}} \mathrm{X}_{6 \mathrm{i}}+\beta_{7 \mathrm{i}} \mathrm{X}_{7 \mathrm{i}}+\beta_{8 \mathrm{i}} \mathrm{X}_{8 \mathrm{i}}+\mathrm{CV}+ \\
& \mathrm{e}_{\mathrm{i}}
\end{aligned}
$$


where:

$\mathrm{Y}_{\mathrm{k}}=$ four dependent variables consist of total sale $\left(\mathrm{Y}_{1}\right)$; net profit $\left(\mathrm{Y}_{2}\right)$, number of employees $\left(\mathrm{Y}_{3}\right)$ and labor productivity $\left(\mathrm{Y}_{4}\right)$.

$\mathrm{X}_{1}=$ backward linkage

$\mathrm{X}_{2}=$ forward linkage

$\mathrm{X}_{3}=$ horizontal linkage

$\mathrm{X}_{4}=$ finance strategy

$\mathrm{X}_{5}=$ marketing strategy

$\mathrm{X}_{6}=$ HRM strategy

$\mathrm{X}_{7}=\mathrm{R} \& \mathrm{D}$ strategy

$\mathrm{X}_{8}=$ operation strategy

$\mathrm{i}=\operatorname{firm} i(\mathrm{i}=1, \ldots, 240)$

\section{Results and Discussions}

\section{Results}

By utilizing simple calculations, the data were calculated as had been formulated in the above models. Table 4 presents various OLS results of the models which showed the impact of inter-firm linkages and business strategies on each performance indicator.

\section{a. Model 1A: sale index}

The first model (column 2 of Table 4) specified the relationship between the interfirm linkages and business strategies on the firm's sales. There is no type of inter-firm linkages that individually affect the sale index. Meanwhile, three types of business strategy variables individually affect the sale index, they are the financial strategy, research and development (R\&D) strategy, and operational strategy indexes $\left(\beta_{4}=0.187\right.$; $\mathrm{t}$ value $=1.898, \beta_{7}=0.168 ; \mathrm{t}$-value $=2.011$, and $\beta_{8}=0.248 ; \mathrm{t}$-value $=2.517$, significant at the confidence level of 95 percent).

\section{b. Model 2A: net profit index}

The second model (column 3 of Table 4) tests the relationship between the interfirm linkages and business strategies on the firm's net profit. The model shows that there is no type of inter-firm linkages which individually affect the net profit index. In the meantime, one type of business strategy variable does individually affect the net profit index, that is the operational strategy index $\left(\beta_{8}=0.322 ; \mathrm{t}\right.$-value $=3.549$, significant at the confidence level of 99 percent). One control variable, that is the firm's size $\left(\beta_{9}=0.221 ; \mathrm{t}\right.$ value $=2.235$, significant at the confidence level of 95 percent) also individually affects the net profit index.

\section{c. Model 3A: asset index}

The third model (column 4 of Table 4) examines the relationship between the interfirm linkages and business strategies on the firm's assets. The model shows that there are two types of inter-firm linkages individually affecting the asset index, they are a backward linkage $\left(\beta_{1}=0.393\right.$; $t$-value $=5.003$, significant at the confidence level of 99 percent) and a horizontal linkage $\left(\beta_{3}=0.159\right.$; $\mathrm{t}$ value $=2.246$, significant at the confidence level of 95 percent). Meanwhile, two types of business strategy variables individually affect the asset index, they are the financial strategy index $\left(\beta_{4}=-0.213 ; \mathrm{t}\right.$-value $=-2.251$, significant at the confidence level of 95 percent) and marketing strategy index $\left(\beta_{5}=\right.$ 0.205 ; $\mathrm{t}$-value $=-2.160$, significant at the confidence level of 95 percent).

\section{d. Model 4A: full-time employees index}

The fourth model (column 5 of Table 4) examines the relationship between the in- 
Table 4. The OLS Results of the Specific Models

\section{Independent}

Variables

Dependent Variables

\begin{tabular}{|c|c|c|c|c|c|c|}
\hline & Sale & Profit & Asset & Labor & Productivity & Performance \\
\hline Constant & $\begin{array}{r}0.900 \\
(2.422)^{*}\end{array}$ & $\begin{array}{r}1.071 \\
(3.133)^{* *}\end{array}$ & $\begin{array}{r}2.086 \\
(5.854)^{* *}\end{array}$ & $\begin{array}{r}1.866 \\
(5.730)^{* *}\end{array}$ & $\begin{array}{r}1.766 \\
(5.637)^{* *}\end{array}$ & $\begin{array}{r}7.670 \\
(6.679)^{* *}\end{array}$ \\
\hline $\begin{array}{l}\text { Backward } \\
\text { Linkage }\end{array}$ & $\begin{array}{r}0.102 \\
(1.253)\end{array}$ & $\begin{array}{r}0.085 \\
(1.128)\end{array}$ & $\begin{array}{r}0.393 \\
(5.003)^{* *}\end{array}$ & $\begin{array}{r}0.154 \\
(2.146)^{*}\end{array}$ & $\begin{array}{r}0.248 \\
(3.585)^{* *}\end{array}$ & $\begin{array}{r}0.990 \\
(3.905) * *\end{array}$ \\
\hline $\begin{array}{l}\text { Forward } \\
\text { Linkage }\end{array}$ & $\begin{array}{r}-0.008 \\
(-0.099)\end{array}$ & $\begin{array}{r}0.107 \\
(1.322)\end{array}$ & $\begin{array}{r}-0.157 \\
(-1.865)\end{array}$ & $\begin{array}{r}-0.091 \\
(-1.182)\end{array}$ & $\begin{array}{r}-0.165 \\
(-2.225)^{*}\end{array}$ & $\begin{array}{r}-0.322 \\
(-1.184)\end{array}$ \\
\hline $\begin{array}{l}\text { Horizontal } \\
\text { Linkage }\end{array}$ & $\begin{array}{r}0.0926 \\
(1.248)\end{array}$ & $\begin{array}{r}0.035 \\
(0.514)\end{array}$ & $\begin{array}{r}0.159 \\
(2.246)^{*}\end{array}$ & $\begin{array}{r}0.141 \\
(2.179)^{*}\end{array}$ & $\begin{array}{r}0.141 \\
(2.263)^{*}\end{array}$ & $\begin{array}{r}0.575 \\
(2.512)^{*}\end{array}$ \\
\hline $\begin{array}{l}\text { Financial } \\
\text { Strategy }\end{array}$ & $\begin{array}{r}0.187 \\
(1.898)^{*}\end{array}$ & $\begin{array}{r}-0.005 \\
(-0.052)\end{array}$ & $\begin{array}{r}-0.213 \\
(-2.251)^{*}\end{array}$ & $\begin{array}{r}0.044 \\
(0.510)\end{array}$ & $\begin{array}{r}-0.231 \\
(-2.778)^{* *}\end{array}$ & $\begin{array}{r}-0.220 \\
(-0.721)\end{array}$ \\
\hline $\begin{array}{l}\text { Marketing } \\
\text { Strategy }\end{array}$ & $\begin{array}{r}0.141 \\
(-1.423)\end{array}$ & $\begin{array}{r}-0.060 \\
(-0.667)\end{array}$ & $\begin{array}{r}-0.205 \\
(-2.160)\end{array}$ & $\begin{array}{r}0.153 \\
(1.766)^{*}\end{array}$ & $\begin{array}{r}-0.222 \\
(-2.662)^{* *}\end{array}$ & $\begin{array}{r}-0.484 \\
(-1.579)\end{array}$ \\
\hline $\begin{array}{l}\text { HRM } \\
\text { Strategy }\end{array}$ & $\begin{array}{r}-0.003 \\
(-0.049)\end{array}$ & $\begin{array}{r}0.032 \\
(0.464)\end{array}$ & $\begin{array}{r}0.132 \\
(1.827)\end{array}$ & $\begin{array}{r}-0.007 \\
(-0.106)\end{array}$ & $\begin{array}{r}0.161 \\
(2.521)^{*}\end{array}$ & $\begin{array}{r}0.316 \\
(1.346)\end{array}$ \\
\hline $\begin{array}{l}\text { R\&D } \\
\text { Strategy }\end{array}$ & $\begin{array}{r}0.168 \\
(2.011)^{*}\end{array}$ & $\begin{array}{r}0.031 \\
(0.412)\end{array}$ & $\begin{array}{r}0.122 \\
(1.524)\end{array}$ & $\begin{array}{r}0.078 \\
(1.069)\end{array}$ & $\begin{array}{r}0.254 \\
(3.597)^{* *}\end{array}$ & $\begin{array}{r}0.652 \\
(2.520)^{*}\end{array}$ \\
\hline $\begin{array}{l}\text { Operational } \\
\text { Strategy }\end{array}$ & $\begin{array}{r}0.248 \\
(2.517)^{*}\end{array}$ & $\begin{array}{r}0.322 \\
(3.549)^{* *}\end{array}$ & $\begin{array}{r}0.144 \\
(1.529)\end{array}$ & $\begin{array}{r}-0.066 \\
(-0.769)\end{array}$ & $\begin{array}{r}0.139 \\
(1.679)\end{array}$ & $\begin{array}{r}0.803 \\
(2.630)^{* *}\end{array}$ \\
\hline Firm Size & $\begin{array}{r}0.087 \\
(0.811)\end{array}$ & $\begin{array}{r}0.221 \\
(2.235)^{*}\end{array}$ & $\begin{array}{r}-0.106 \\
(-1.035)\end{array}$ & $\begin{array}{r}-0.298 \\
(-3.165)^{* *}\end{array}$ & $\begin{array}{r}0.013 \\
(0.143)\end{array}$ & $\begin{array}{r}-0.077 \\
(-0.233)\end{array}$ \\
\hline Firm Age & $\begin{array}{r}-0.006 \\
(-1.218)\end{array}$ & $\begin{array}{r}-0.004 \\
(-0.954)\end{array}$ & $\begin{array}{r}-0.006 \\
(-1.352)\end{array}$ & $\begin{array}{r}-0.006 \\
(-1.381)\end{array}$ & $\begin{array}{r}-0.003 \\
(-0.930)\end{array}$ & $\begin{array}{r}-0.027 \\
(-1.754)\end{array}$ \\
\hline $\begin{array}{l}\text { Entrepreneur } \\
\text { Age }\end{array}$ & $\begin{array}{r}-0.001 \\
(-0.200)\end{array}$ & $\begin{array}{r}0.001 \\
(0.249)\end{array}$ & $\begin{array}{r}-0.003 \\
(-0.642)\end{array}$ & $\begin{array}{r}0.001 \\
(0.382)\end{array}$ & $\begin{array}{r}0.001 \\
(0.148)\end{array}$ & $\begin{array}{r}-0.001 \\
(-0.053)\end{array}$ \\
\hline $\begin{array}{l}\text { Education } \\
\text { Level }\end{array}$ & $\begin{array}{r}0.079 \\
(1.853)\end{array}$ & $\begin{array}{r}0.007 \\
(0.195)\end{array}$ & $\begin{array}{r}0.028 \\
(0.704)\end{array}$ & $\begin{array}{r}0.017 \\
(0.469)\end{array}$ & $\begin{array}{r}0.067 \\
(1.860)\end{array}$ & $\begin{array}{r}0.202 \\
(1.536)\end{array}$ \\
\hline $\mathrm{R}^{2}$ & 0.275 & 0.298 & 0.255 & 0.200 & 0.314 & 0.349 \\
\hline $\mathrm{D}-\mathrm{W}$ & 1.734 & 1.806 & 1.349 & 1.189 & 1.649 & 1.428 \\
\hline F-CalSig. & $\begin{array}{r}6.924 \\
(0.000)\end{array}$ & $\begin{array}{r}7.777 \\
(0.000)\end{array}$ & $\begin{array}{r}6.248 \\
(0.000)\end{array}$ & $\begin{array}{r}4.584 \\
(0.000)\end{array}$ & $\begin{array}{r}8.358 \\
(0.000)\end{array}$ & $\begin{array}{r}9.823 \\
(0.000)\end{array}$ \\
\hline
\end{tabular}

Note: - * and $* *$ statistically significant at, $5 \%$ and $1 \%$ level, respectively.

- Tolerances vary from 0.409 to 0.803 and Variance Inflation Factors (VIF) vary

From 1.245 to 2.446 indicated that there is no multicollinearity. 
ter-firm linkages and business strategies on the firm's full-time employees. The model shows that there are two types of inter-firm linkages that individually affect the labor index, they are a backward linkage $\left(\beta_{1}=0.154\right.$; $\mathrm{t}$-value $=2.146$, significant at the confidence level of 95 percent) and a horizontal linkage $\left(\beta_{3}=0.141 ; \mathrm{t}-\mathrm{value}=2.179\right.$, significant at the confidence level of 95 percent). In the meantime, one type of business strategy variable, the marketing strategy $\left(\beta_{5}=0.153 ; \mathrm{t}\right.$ value $=1.766$, significant at the confidence level of 95 percent) individually affects the number of full-time employees index. One control variable, the size of the firm $\left(\beta_{9}=-\right.$ 0.298 ; $\mathrm{t}$-value $=-3.165$, significant at the con- fidence level of 99 percent), also individually affects the number of full-time employees index.

\section{e. Model 5A: productivity index}

The last model (column 6 of Table 4) examines the relationship between the interfirm linkages and business strategies on the employees' productivity. The model shows that all types of inter-firm linkages individually affect the productivity index, they are the backward linkage $\left(\beta_{1}=0.248\right.$; $t$-value $=3.585$, significant at the confidence level of 99 percent), and the forward and horizontal linkages $\left(\beta_{2}=-0.165 ; \mathrm{t}-\mathrm{value}=-2.225\right.$, and $\beta_{3}=0.141 ; \mathrm{t}$-value $=2.263$, significant at the

Table 5. The OLS Results of the General Models

\begin{tabular}{|c|c|c|c|c|c|c|}
\hline \multicolumn{3}{|c|}{$\begin{array}{l}\text { Independent } \\
\text { Variables }\end{array}$} & \multicolumn{3}{|c|}{ Dependent Variables } & \multirow[b]{2}{*}{$\begin{array}{c}\text { Total } \\
\text { Performance } \\
7 \\
\end{array}$} \\
\hline 1 & $\begin{array}{c}\text { Sale } \\
2 \\
\end{array}$ & $\begin{array}{c}\text { Profit } \\
3 \\
\end{array}$ & $\begin{array}{c}\text { Asset } \\
4 \\
\end{array}$ & $\begin{array}{c}\text { Lab or } \\
5 \\
\end{array}$ & $\begin{array}{c}\text { Productivity } \\
6 \\
\end{array}$ & \\
\hline $\begin{array}{l}\text { Inter-Firm } \\
\text { Linkages }\end{array}$ & $\begin{array}{r}0.019 \\
(2.420)^{*}\end{array}$ & $\begin{array}{r}0.017 \\
(2.383)^{*}\end{array}$ & $\begin{array}{r}0.016 \\
(2.045)^{*}\end{array}$ & $\begin{array}{r}0.006 \\
(0.946)\end{array}$ & $\begin{array}{r}-0.001 \\
(-0.164)\end{array}$ & $\begin{array}{r}0.057 \\
(2.300)^{*}\end{array}$ \\
\hline $\begin{array}{l}\text { Business } \\
\text { Strategies }\end{array}$ & $\begin{array}{r}0.092 \\
(6.212)^{* *}\end{array}$ & $\begin{array}{r}0.076 \\
(5.535)^{* *}\end{array}$ & $\begin{array}{r}0.045 \\
(2.938)^{* *}\end{array}$ & $\begin{array}{r}0.051 \\
(1.896)^{* *}\end{array}$ & $\begin{array}{r}0.060 \\
(4.397)^{* *}\end{array}$ & $\begin{array}{r}0.323 \\
(6.761)^{* *}\end{array}$ \\
\hline Firm Size & $\begin{array}{r}0.128 \\
(1.320)\end{array}$ & $\begin{array}{r}0.308 \\
(3.404)^{* *}\end{array}$ & $\begin{array}{r}-0.166 \\
(-1.654)\end{array}$ & $\begin{array}{r}-0.405 \\
(-4.725)\end{array}$ & $\begin{array}{r}-0.067 \\
(-0.742)\end{array}$ & $\begin{array}{r}-0.195 \\
(-0.618)\end{array}$ \\
\hline Firm Age & $\begin{array}{r}-0.009 \\
(-1.941)\end{array}$ & $\begin{array}{r}-0.007 \\
(-1.582)\end{array}$ & $\begin{array}{r}-0.008 \\
(-1.616)\end{array}$ & $\begin{array}{r}-0.004 \\
(-1.154)\end{array}$ & $\begin{array}{r}-0.007 \\
(-1.667)\end{array}$ & $\begin{array}{r}-0.036 \\
(-2.376)^{*}\end{array}$ \\
\hline $\begin{array}{l}\text { Entrepreneur } \\
\text { Age }\end{array}$ & $\begin{array}{r}0.002 \\
(0.420)\end{array}$ & $\begin{array}{r}0.006 \\
(1.190)\end{array}$ & $\begin{array}{r}-0.003 \\
(-0.537)\end{array}$ & $\begin{array}{r}-0.001 \\
(-0.060)\end{array}$ & $\begin{array}{r}0.001 \\
(0.053)\end{array}$ & $\begin{array}{r}0.005 \\
(0.296)\end{array}$ \\
\hline $\begin{array}{l}\text { Education } \\
\text { Level }\end{array}$ & $\begin{array}{r}0.066 \\
(1.601)\end{array}$ & $\begin{array}{r}-0.014 \\
(-0.369)\end{array}$ & $\begin{array}{r}0.041 \\
(0.972)\end{array}$ & $\begin{array}{r}0.018 \\
(0.501)\end{array}$ & $\begin{array}{r}0.097 \\
(2.560)^{*}\end{array}$ & $\begin{array}{r}0.210 \\
(1.583)\end{array}$ \\
\hline $\mathrm{R}^{2}$ & 0.239 & 0.195 & 0.098 & 0.153 & 0.137 & 0.251 \\
\hline D-W & 1.676 & 1.631 & 1.245 & 1.102 & 1.434 & 1.326 \\
\hline $\begin{array}{l}\text { F-Cal } \\
\text { Sig. }\end{array}$ & $\begin{array}{c}11.764 \\
\mathbf{( 0 . 0 0 0 )}\end{array}$ & $\begin{array}{c}27.892 \\
\mathbf{( 0 . 0 0 0 )}\end{array}$ & $\begin{array}{r}4.059 \\
(\mathbf{0 . 0 0 1 )}\end{array}$ & $\begin{array}{r}6.763 \\
(\mathbf{0 . 0 0 0 )}\end{array}$ & $\begin{array}{r}5.934 \\
(\mathbf{0 . 0 0 0 )}\end{array}$ & $\begin{array}{c}12.584 \\
(\mathbf{0 . 0 0 0 )}\end{array}$ \\
\hline
\end{tabular}

Note. - * and ${ }^{* *}$ statistically significant at, 5 percent and 1 percent level, respectively. 
confidence level of 95 percent). In this model the forward linkage has a negative sign.

Meanwhile, four types of business strategy variables individually affect the productivity index. They are the financial strategy, marketing strategy, $R \& D$ strategy $\left(\beta_{4}=-0.231\right.$; $\mathrm{t}-\mathrm{value}=-2.778, \beta_{5}=-0.222 ; \mathrm{t}$-value $=-2.662$, $\beta_{7}=0.254$; $t$-value $=3.597$, significant at the confidence level of 99 percent), and the HRM strategy $\left(\beta_{6}=0.161\right.$; $\mathrm{t}$-value $=2.521$, significant at the confidence level of 95 percent). There is no control variable that individually affects the productivity index in this model.

Summarizing the above individual variable relationships, the OLS calculation provided the relationships for the inter-firm linkages and business strategies toward the MSEs' performance in the general models. Table 5 presents such relationships.

\section{Discussions}

The models developed above provided the theoretical framework for understanding the complex phenomena of the relationship between the inter-firm linkages and business strategies applied simultaneously to the performance of the MSEs operating within small industrial clusters in East Java. Through regression analysis of the 240 sampled MSEs this study found the simultaneity of the inter-firm linkages and business strategies exist in the business operations and that both affect the MSEs' performance. In this regard, the MSEs' performance consists of total sales, net profits, assets, the number of fulltime employees, and worker productivity.

However, the findings revealed that the impacts of the inter-firm linkages on the MSEs' performance are less effective than that of their business strategies. Among the models, the inter-firm linkages simply affected the firm's sales, profits, and assets. Meanwhile their business strategies affected all the indicators of total performance as can be seen in Table 5 .

Related to the inter-firm linkages, forward linkages in fact negatively affected worker's productivity in MSEs operated in clusters, as shown in Table 4. The negative sign for forward linkage is interesting, and needs to be analyzed, as research on the role of the linkage on firms' performance have been positively proved by many previous researchers. Kelegama and Foley (1999) showed that forward linkages are very useful in reducing the lead time for the garment industry in Sri Lanka. Mazzola and Bruni (2000) provided evidence that forward linkages have positive effects on firms' performance in small southern Italian firms. While Ismalina (2009) proved that the forward subcontracting relationships that were developed by trust could reduce the cost of information, process requirements and other variables that determined the progress of the high-quality products of a ceramic cluster in Yogyakarta.

One likely reason why the forward linkages negatively influenced firms' performance in the clustered MSEs in East Java was the absence of trust among the entrepreneurs and the existence of institutional problems. Following Ismalina (2009), the absence of trust caused the emergence of opportunistic behavior that led entrepreneurs to reap the benefits from the forward linkage for their own interest, thus failing to achieve the collective efficiency offered by the linkage. Some problems emerge with this linkage, such as in forward subcontracting and dependency in product marketing, which cause the forward linkage to negatively contribute to firms' performance. 
A point which emerged from the Focused Group Discussion with the micro and small entrepreneurs of the furniture cluster in the sub district of Tunjung Sekar, Malang, was that it was problematic to make effective forward linkages with business partners. Due to their limited capacity, small firms need a certain level of product distribution to achieve effective marketing, but their partners often used this cooperation for their own interests. One of the respondents stated:

"To sell our products we usually distribute them to the bigger firms that have a product showroom. The showroom is very important as it should be located near the main street. However, our partners often display and sell their own products instead of our products. The result of this cooperation....we are still in a marginal position whereas our partners are getting bigger and bigger."

In relation to orders given by the local government, the respondent accordingly stated that such a business relationship is not an aid to improving the business but that the government's orders in fact destroy it:

"We often obtain orders given by the local government of Malang City. However, the products cannot be finished well as the officerforces us to work overtime. The products that should be finished in four months must be finished in two months as the officer demanded. This absolutely disturbs our working mechanisms as we cannot get our optimum profit."

Contrarily, the backward and horizontal linkages positively affected the clustered MSEs firms' performance, especially on the firm's assets, employees, and worker productivity as can be seen in Table 4. Many scholars, such as Altenburg and Meyer-Stamer (1999), proved that clustering MSEs had horizontal benefits to such enterprises, and entail some positive externalities such as the availability of a semi-skilled labor force, and information spillover concerning sourcing, marketing, and the product design of com- petitors. Rabellotti (1998) showed that such positive externalities are commonly derived from unplanned, incidental relationships among the entrepreneurs whointer-act within the system. These inter-actions then generate both static and dynamic external economies which usually freely circulate within the districts. In the case of the small industrial clusters in East Java, this study has demonstrated that backward and horizontal linkages clearly affect the MSEs' performance.

In terms of business strategies, the models show that all indicators of business strategies have a positive effect on all the clustered MSE firms. Porter (1990, 2000), in his diamond model, considered a firm's strategy as a factor that motivates the clustered firms to enhance product quality and search for new innovations. Bender et al. (2002) insisted that while firms in the clusters cooperate with each other, the firm's strategy and rivalry matter because this rivalry, in the form of intense domestic competition, spurs innovation in which the optimal levels of competition and cooperation vary by industry and region. Furthermore, Gelderen at al. (2000) stated that as a result of the entrepreneur's dominance in decision making in small firms, the personal strategy that the entrepreneur uses will influence his firm's performance. This study clearly proved that the presence of business strategies matter for those MSEs that operate in small industrial clusters widely dispersed in East Java as the strategies positively associate with the firms' performance.

\section{Conclusion}

This study attempted to examine the application of the inter-firm linkages and business strategies of the MSEs that operate in small industrial clusters in East Java. It is 
proved that both inter-firm linkages and business strategies matter and affect the performance of the MSEs that operate in such clusters.

Viewed from the co-opetition strategy perspective, this study has added to the growing stream of literature on strategy and entrepreneurship, dealing with the competitiveness of MSEs operated within clusters. Although many scholars have augmented our understanding of particular issues involved in these small industrial clusters, there are only a few studies that focus on how the potentially conflicting forces in clustered MSEs, as a result of cooperation and competition applied simultaneously, are reconciled. This study has provided a distinctive perspective with respect to what actually happens in these small industrial clusters by putting forth the model of the clusters based on both the cooperation and competition perspective. This study has integrated the different activities of cooperation and competition by putting both the inter-firm linkages and business strategies into the models and revealed their degree of effectiveness on the MSE firms' performances when operating in small industrial clusters.

\section{References}

Albu, M. 1997. Technological learning and innovation in industrial clusters in the south. SPRU (Electronic Working Paper Series) (Paper No 7).

Altenburg, T., and J. Meyer-Stamer. 1999. How to promote clusters: Policy experiences from latin America. World Development 27 (9): 1693-1713.

Ayyagari, M. (2006). Micro and Small Enterprises: Unexplored Pathways to Growth. MicroREPORT \#63. IRIS Center, University of Maryland. USA.

Bender, C., P. Harms, and G. Rindermann.2002. Do Clusters Matter? Empirical Evidence from Germany's Neuer Markt. International Business Department, University of Muenster, Germany.

Bengtsson, M., and S. Kock. 2000. Coopetition in business networks-to cooperate and compete simultaneously. Industrial Marketing Management 29 (5): 411-426.

Chong, H. G. 2008. Measuring performance of small-and-medium seized enterprises: The grounded theory approach. Journal of Business and Public Affairs 2 (1).

Cragg, P., M. King, and H. Hussin. 2002. IT alignment and firm performance in small manufacturing firms. Journal of Strategic Information Systems 11: 109-132.

Dagnino, G. B., and G. Padula. 2002. Coopetition strategy a new kind of interfirm dynamics for value creation. Paper presented at EURAM - The European Academy of Management, Second Annual Conference - "Innovative Research in Management". Stockholm, 9-11 May 2002.

Delmar, F. 1997. Measuring growth: Methodological considerations and empirical results. In Donckles, R. and A. Miettinen (Eds), Entrepreneurship and SME Research: on its Way to the Next Millenium. Ashgate Publishing Ltd, Aldershot. England.

Edström, A., and B. Högberg. 2007. The Strategic Context of Interfirm Co-operation. Synopsis of Working Paper 77-22. European Institute for Advanced Studies in Management. Brussels.

Freel, M. S. 2003. Sectoral patterns of small firm innovation, networking and proximity. Research Policy 32: 751-770. 
Fu, X., A. Eisingerich, and R. De Hoyos. 2008. Clusters of management practices, structural embeddedness and firm productivity. SLPTMD Working Paper Series No.008.

Garg, V. K., B. A. Walters, and R. L. Priem. 2003. Chief executive scanning emphases, environmental dynamism and manufacturing firm performance. Strategic Management Journal 24 (8).

Gelderen, M., M. Frese, and R. Thurik. 2000. Strategies, uncertainty and performance of small business startups. Small Business Economics 15: 165-181.

Gnyawali, D. R., He, J., and Madhavan, R. (2006). Impact of Co-Opetition on Firm Competitive Behavior: An Empirical Examination. Journal of Management, Vol. 32 No. 4, August: 507-530.

Ha, T. T. 2002. Entrepreneurial orientation, business strategies and firm performance: A comparative study of small medium-scale enterprises in Vietnam and Thailand. Dissertation Work at Asian Institute of Technology. Thailand.

Henry, M. S., D. L. Barkley, and Y. Zhang. 1997. Industry clusters in the TVA region: Do they affect development or rural areas? Contractor Paper 98-9. TVA Rural Studies Program.

Hirschman, A. O. 1988. The strategy of economic development. A Westview Encore Edition. Westview Press. Boulder \& London.

IDS Policy Briefing. 1997. Collective Efficiency: a Way Forward for Small Firms (Issue 10) (April). UK. Institute of Development Studies.

Ismalina, P. 2009. The socio-economic structure of industrial clusters: A case study of three selected Indonesian industrial clusters. Paper presented at the $15^{\text {th }}$ Spring Meeting of Young Economists (SMYE-2009). Istanbul, 23-25 April.

Janczak, S., and F. Bares. 2010. High growth SMEs: The evolution of the gazelles and some evidence from the field. Working Paper no: 2010-01. HEC MONTRÉAL.

Kelegama, S., and F. Foley. 1999. Impediments to promoting backward linkages from the garment industry in Sri Lanka. World Development 27 (8): 1445-1460.

Knorringa, P., and I. van Staveren. 2006. Social Capital for Industrial Development: Operationalizing the Concept. United Nations Industrial Development Organi-zation (UNIDO). Vienna.

Kongmanila, X., and Y. Takahashi. 2009. Inter-firm cooperation and firm performance: An empirical study of the Lao garment industry cluster. International Journal of Business and Management (4) (5) (May).

Kotey, B., and M. Harker. 1998. A Framework for Examining Strategy and Strategy Types in Small Firms. ICSB.

Kristiansen, S. 2003. Linkages and rural non-farm employment creation: Changing challenges and policies in Indonesia. ESA Working Paper (03-22) (December).

Kuncoro, M. 2002. A quest for industrial districts: an emperical study of manufacturing industries in Java. Paper presented in international workshop on the theme "Economic Growth and Institutional Change in Indonesia during the $19^{\text {th }}$ and $20^{\text {th }}$ Centuries". Amsterdam. February, 25-26.

Kuncoro, M., and I. A. Supomo. 2003. Analisis formasi keterkaitan, pola klaster, dan orientasi pasar: Studi kasus sentra industri keramik di Kasongan, Bantul, D.I. Yogyakarta. Jurnal Empirika Volume 16 (1) (Juni).

Le Roy, F., and S. Yami. 2009. Coopetition and entrepreneurship. International Journal of Entrepreneurship \& Small Business 8 (1): $1-5$. 
Lemma, S. 2001. Subcontracting strategy for the Ethiopian micro and small enterprises. Study Report submitted to Ethio-German Micro and Small Enterprises Development Programme. Addis Ababa, Ethiopia. July 2001.

Li, and Fung. 2006. Overview of the industrial clusters in China. Industrial Cluster Series (1) (May). Li \& Fung Research Centre.

Machikita, T., and Y. Ueki. 2010. Innovation in linked and non-linked firms: Effects of variety of linkages in East Asia. ERIA Discussion Paper Series: ERIA-DP-2010-3.

Maes, J., L. Sels, and F. Roodhoft. 2003. Modeling small business profitability: An empirical test in the construction industry. Paper presented at the Academy of Annual Management Meeting, August 16 , Seattle (WA).

Makkonen, M. 2008. Co-opetition: Coexistence of cooperation and competition in public sector - A case study in one city's public companies. Thesis work at LUT, School of Business. Lappeenranta University of Technology. Finland.

Mazzola, F., and S. Bruni. 2000. The role of linkages in firm performance: evidence from southern Italy. Journal of Economic Behavior and Organization 43: 199-221.

McCartney, M. 2006. Comparative advantage and sustainable economic growth in India after 1991. Paper presented at International Conference on the Indian Economy in the Era of Financial Globalization. 28-29 September.

Miehlbradt, A. O., and M. McVay. 2006. Implementing Sustainable Private Sector Development: Striving for Tangible Results for the Poor: The 2006 Reader. International Training Centre of the ILO.

Morris, M. H., A. Koçak, and A. Õzer. 2007. Coopetition as small business strategy: Implications for performance. Journal of Small Business Strategy 18 (1) (Spring/Summer): 35-55.

Nadvi, K. 1999. Collective efficiency and collective failure: The response of sialkot surgical instrument cluster to global quality pressures. World Development 27 (9): 1605-1626.

O’Regan, N., Sims, M., and A. Ghobadian. 2004. The impact of management techniques on the performance of technology based firms. Technovation.

Parrilli, M. D. 2001. The heterogeneity of small enterprises: A key for industrial policies in Nicaragua. Industrial Development Policy Discussion Paper 13.

Porter, M. E. 1990. The Competitive Advantage of Nations. The Free Press a Division of Macmillan, Inc. New York.

Porter, M. E. 2000. Location, competition, and economic development: Local clusters in a global economy. Economic Development Quarterly, Vol. 14, No. 1.

Poshtuma, A. C. 2003. Taking a seat in the global marketplace: Opportunities for "high road" upgrading in the Indonesian wood furniture sector? Paper presented at the conference on Clusters, Industrial Districts and Firms: the Challenge of Globalization. Modena, Italy. 12-13 September.

Rabellotti, R. 1998. Collective effects in Italian and Mexican footwear industrial clusters. Small Business Economics 10: 243-262.

Roda, J., P. Cadène, P. Guizol, L. Santoso, and A. U, Fauzan. 2007. Atlas of Wooden Furniture Industry in Jepara, Indonesia. Bogor. CIRAD and CIFOR, <http://www.cifor.cgiar.org/publications/pdf_files/ Books/BRoda0701> (Accessed on 4 January 2009)

Sandee, H., P. Rietveld, H. Supratikno, and P. Yuwono. 1994. Promoting small scale and cottage industries in Indonesia: An impact analysis for Central Java. Bulletin of Indonesian Economic Studies 30 (3). 
Sato, Y. 2000. Linkage formation by small firms: The case of rural cluster in Indonesia. Bulletin of Indonesian Economic Studies 36 (1): 137- 166.

Schmitz, H., 1995. Collective efficiency: Growth path for small scale Industry. The Journal of Development Studies 31 (4).

Smallbone, D., R. Leigh, and D. North. 1995. The characteristics and strategies of high growth SMEs. International Journal of Entrepreneurial Behavior and Research 1 (3).

Solitander, M., and A. Tidström. 2010. Competitive flows of intellectual capital in value creating networks. Journal of Intellectual Capital 11 (1): 23-38.

Tambunan, T. 2006. Development of Small and Medium-Scale Industry Clusters in Indonesia. KADIN Indonesia. Jetro, http://www.kadin-indonesia.or. id/en/doc/opini/ Development_Of_Small\&MediumScale_ Industy_Clusters

Tarmidi, L. T. 2005. The importance of MSEs in economic development of developing APEC countries. Paper presented at the APEC Study Center Consortium Conference, 22-25 May 2005. Jeju, Korea, <http://www.apec.org .au/docs/korea papers2/SVII-LT-Paper.pdf> (Accessed on 16 December 2008).

UNIDO. 2010. Cluster Development for Pro-Poor Growth: The UNIDO Approach. The United Nations Industrial Development Organization. Vienna.

Vangstrup, U. 1997. Globalization of industry in Mexico - a commodity chain approach to the analysis of linkage-capabilities. Paper presented at the 1997 meeting of the Latin American Studies Association. Guadalajara, Mexico. 17-19 April.

Walker, E., K. Loughton, and A. Brown. 1999. The Relevance of Non-Financial Measure of Success for Micro Business Owners. ICSB.

Weijland, H. 1999. Microenterprise clusters in rural Indonesia: Industrial seedbed and policy target. World Development 27 (9): 1515-1530. 
